\title{
PRESEPSI WISATAWAN TERHADAP POTENSI KEPARIWISATAAN OBJEK WISATA ALAM PANTAI OETUNE DI KABUPATEN TIMOR TENGAH SELATAN NUSA TENGGARA TIMUR
}

\author{
Theodora Murni C. Tualaka, T. Yoyok Wahyu Subroto, Djoko Wijono \\ (email: tualaka.murni@gmail.com)
}

\begin{abstract}
ABSTRAK
Tujuan penelitian adalah untuk mengidentifikasikan potensi kepariwisataan Pantai Oetune yang menghasilkan rekomendasi pengembangan dan perbaikan kualitas, serta untuk mengetahui faktor paling berpengaruh dalam meningkatkan potensi sesuai dengan ekspektasi wisatawan. Metode penelitian yang digunakan adalah metode deskriptif kualitatif kuantitatif dengan fokus penilaian berdasarkan ekspektasi wisatawan. Teknik pengumpulan data menggunakan kuesioner, wawancara, observasi, studi pustaka dan dokumentasi. Hasil pengambilan data kemudian dianalisis menggunakan pendekatan kuantitatif dan perhitungan SPSS. Hasil penelitian menunjukkan bahwa destinasi wisata alam Pantai Oetune memiliki potensi sebagai berikut: 1) Keaslian/kealamian sebab kawasan pantai masih alami dan belum didesain ulang; 2) Keindahan yaitu variasi pandangan, kerindangan tepi pantai dan keserasian dengan lingkungan; dan 3) Keunikan berupa gumuk pasir, sabana dalam kawasan, gradasi warna laut, bentangan luas dan variasi pemandangan. Pengembangan potensi yang sesuai dengan ekspektasi wisatawan yaitu tetap menjaga serta melestarikan kealamian/keaslian, keindahan pantai dan tersedianya amenitas. Faktor paling berpengaruh terhadap peningkatan potensi Pantai Oetune adalah faktor lingkungan yang. merupakan daya tarik utama terjadinya aktivitas berwisata.
\end{abstract}

Kata Kunci:

kepariwisataan bahari, potensi, persepsi, daya tarik wisata alam

\begin{abstract}
The research purpose was identifying tourism potentials of Oetune Beach to make recommendations to develop an improve quality, and identifying the most influential factor in improving potentials based on tourists' expectations. The research method was descriptive qualitative and quantitative focusing on assessment based on tourists' expectations. Data was collected by questionnaire, interview, observation, literature study, and documentation. The data collection result was then analyzed by quantitative approach
\end{abstract}


and SPSS. The research result shows that Oetune has the following potentials: 1) Pristineness/naturalness because the beach area is still natural and not yet redesigned; 2) Beauty which is variation of views, shades in the beach, and harmony with the surroundings; and 3) Uniqueness of sand dunes, savanna, seawater gradation, large expanse and variation of views. The development of potentials in accordance with tourists' expectation is preservation of naturalness, beauty of the beach, and availability of amenity. The factor influencing the improvement of the potentials of Oetune Beach is environment which is the main attraction of tourism activities.

\section{Keywords:}

marine tourism, potential, perception, natural tourist attraction

\section{PENDAHULUAN}

Pariwisata sebagai fenomena modern mulai ditelusuri dari perjalanan Marcopolo (12541324) yang menjelajahi Eropa sampai Tiongkok dan kembali ke Venesia. (Pitana dan Diarta, 2009). Fenomena ini terus berkembang hingga ke Indonesia dengan sumber daya wisata pantai yang berkembang pesat. Salah satu daerah potensial wisata pantai di Indonesia yang mendapat dukungan dari pemerintah adalah Provinsi Nusa Tenggara Timur.

Pariwisata NTT, dalam pengembangannya mulai mendapat dukungan dari pemerintah seperti adanya Peraturan Pemerintah Republik Indonesia Nomor 50 Tahun 2011 tentang Rencana Induk Pembangunan Kepariwisataan Nasional Tahun 2010 -2015, dimana Kupang termasuk dalam Destinasi Pariwisata Nasional (DPN) Kupang-Rotendao dan sekitarnya, dengan Kawasan Pengembangan Pariwisata Nasional (KPPN) Kawasan Kupang-So'e dan sekitarnya. Adanya Bandar Udara El-Tari yang merupakan pintu masuk utama menuju seluruh pulau di NTT yang dalam pengembangannya akan dibangun menjadi bandara berstatus internasional dengan kerja sama awal antara Indonesia, Timor Leste dan Australia. Dukungan pariwisata tersebut semakin digencarkan dengan program Pemerintah Provinsi Nusa Tenggara dengan upaya pengembangan pariwisata yaitu "Visit NTT" yang telah dimulai sejak tahun 2009 hingga saat ini.

Salah satu pantai yang mulai dikunjungi masyarakat sekitar selama 2 tahun terakhir adalah Pantai Oetune. Pantai Oetune dianggap memiliki daya tarik berupa kealamian/keaslian, keindahan, kebersihan dan keindahan Beberapa sumber mengatakan bahwa Pantai Oetune memang memiliki potensi sebagai objek wisata, namun fasilitas pendukung yang minim, tidak tersedianya penerangan dan ketersediaan air bersih masih menjadi kendala utama. Berdasarkan latar belakang tersebut, maka penelitian dilakukan untuk mengidentifikasikan potensi pengembangan dan rekomendasi pengembangan sebagai destinasi wisata.

Latar belakang tersebut merumuskan masalah yaitu 1) Potensi kepariwisataan di destinasi wisata alam Pantai Oetune, belum dikembangkan secara maksimal; serta 2) Kondisi potensi kepariwisataan di destinasi wisata alam Pantai Oetune (supply) belum sesuai dengan ekspektasi wisatawan (demand).

Dari rumusan masalah tersebut, maka pertanyaan penelitian yang didapat adalah sebagai berikut.

1. Seperti apakah potensi kepariwisataan destinasi wisata alam Pantai Oetune di Kabupaten Timor Tengah Selatan, Provinsi Nusa Tenggara Timur saat ini?

2. Seperti apakah potensi dan pengembangan kepariwisataan di destinasi wisata alam Pantai Oetune yang sesuai dengan ekspektasi wisatawan?

3. Faktor apakah yang berpengaruh dalam meningkatkan potensi kepariwisataan destinasi wisata alam Pantai Oetune?

Uraian permasalahan tersebut untuk merumuskan tujuan berikut.

1. Mengetahui potensi kepariwisataan destinasi wisata alam Pantai Oetune saat ini. 
2. Merumuskan potensi dan pengembangan sesuai dengan ekspektasi wisatawan.

3. Merumuskan faktor berpengaruh dalam meningkat potensi kepariwisataan dan pengembangan destinasi wisata alam Pantai Oetune.

\section{METODE PENELITIAN}

Metode yang digunakan dalam penelitian adalah metode deskriptif kualitatif dan kuantitatif dengan fokus penilaian potensi kepariwisataan yang sesuai dengan ekspektasi wisatawan dalam proses pengembangannya. Berikut ini tabel metode dan teknik analisis data.

Tabel 1. Metode dan Teknik Analisis Sata

\begin{tabular}{|c|c|c|}
\hline Variabel & $\begin{array}{l}\text { Metode } \\
\text { Analisis } \\
\text { Data }\end{array}$ & $\begin{array}{l}\text { Teknik } \\
\text { Analisis Data }\end{array}$ \\
\hline Potensi Internal & \multirow{4}{*}{$\begin{array}{l}\text { Deskriptif } \\
\text { kualitatif } \\
\& \\
\text { Deskripsi } \\
\text { Kuantitatif }\end{array}$} & $\begin{array}{l}\text { Analisis } \\
\text { Pengumpulan data } \\
\text { Reduksi Data } \\
\text { Display Data }\end{array}$ \\
\hline \multirow{3}{*}{ Potensi Eksternal } & & Penarikan kesimpulan \\
\hline & & Pembahasan \\
\hline & & Kesimpulan \\
\hline
\end{tabular}

Alat yang digunakan untuk menganalisis data dalam penelitian ini adalah dari diri penulis, perhitungan menggunakan excel dan software SPSS. Sedangkan skala pengukuran yang digunakan untuk mengukur nilai responden adalah skala likert. Skala likert digunakan untuk mengukur sikap, pendapat, dan persepsi seseorang atau sekelompok tentang kejadian atau gejala sosial. Penilaian ini berbentuk checklist, dimana angka 1 menunjukkan nilai terendah dan angka 5 menunjukkan nilai tertinggi.

Berikut tabel bobot penilaian skala likert dalam penelitian:
Tabel 2. Gradasi Nilai

\begin{tabular}{|l|l|}
\hline Gradasi Nilai & Skor \\
\hline Sangat Tidak Setuju (STS) & 1 \\
\hline Tidak Setuju (ST) & 2 \\
\hline Netral (N) & 3 \\
\hline Setuju (S) & 4 \\
\hline Sangat Setuju (SS) & 5 \\
\hline
\end{tabular}

Sumber: Riduwan dan Akdon, 2013 dalam Hermalita, 2014; Dimodifikasi penulis, 2017

Setelah mendapatkan jumlah penilaian responden, analisis persepsi dilakukan dengan perkalian gradasi jawaban yang didapat dengan jumlah (frekuensi) responden yang memilih gradasi jawaban tersebut. Nilai ini kemudian dikelompok menjadi kelas potensial.

Tabel 3. Kelas Kategori Potensial

\begin{tabular}{|l|l|l|}
\hline Kategori & Jumlah Skor & Rata-Rata \\
\hline Sangat Tidak Potensial & $65-117$ & $1-1,8$ \\
\hline Tidak Potensial & $117-169$ & $1,8-2,6$ \\
\hline Potensial Sedang & $169-221$ & $2,6-3,4$ \\
\hline Potensial & $221-273$ & $3,4-4,2$ \\
\hline Sangat Potensial & $273-325$ & $4,2-5$ \\
\hline
\end{tabular}

Sumber: Riduwan dan Akdon, 2001; Dimodifikasikan oleh penulis, 2017.

\section{HASIL DAN PEMBAHASAN}

\section{Gambaran Umum Lokasi Penelitian}

Pantai Oetune adalah pantai yang terletak di Desa Tuafanu, Kabupaten Timor Tengah Selatan (TTS), Nusa Tenggara Timur (NTT). Secara geografis TTS terletak pada koordinat $120^{\circ} 4^{\prime}$ $00^{\prime \prime}$ BT - $124^{\circ} 49^{\prime} 0^{\prime \prime}$ BT dan $9^{\circ} 28^{\prime} 13^{\prime \prime}$ LS - $10^{\circ}$ $10^{\prime} 26^{\prime \prime}$ LS. Topografi didominasi oleh dataran aluvial datar sampai berkemiringan landai. Desa Tuafanu memiliki ketinggian $13 \mathrm{~m}$ dari permukaan laut. Sedangkan tekstur tanahnya berupa tanah berpasir. Berdasarkan hidrologi, maka sumber air berasal dari air hujan, air tanah dan air permukaan. Suhu di lokasi berkisar antara $27 \mathrm{oC}-29$ oC. Kelembaban udara 85,5\% per tahun, dan kecepatan angin rata-rata 12 - 20 knots. 


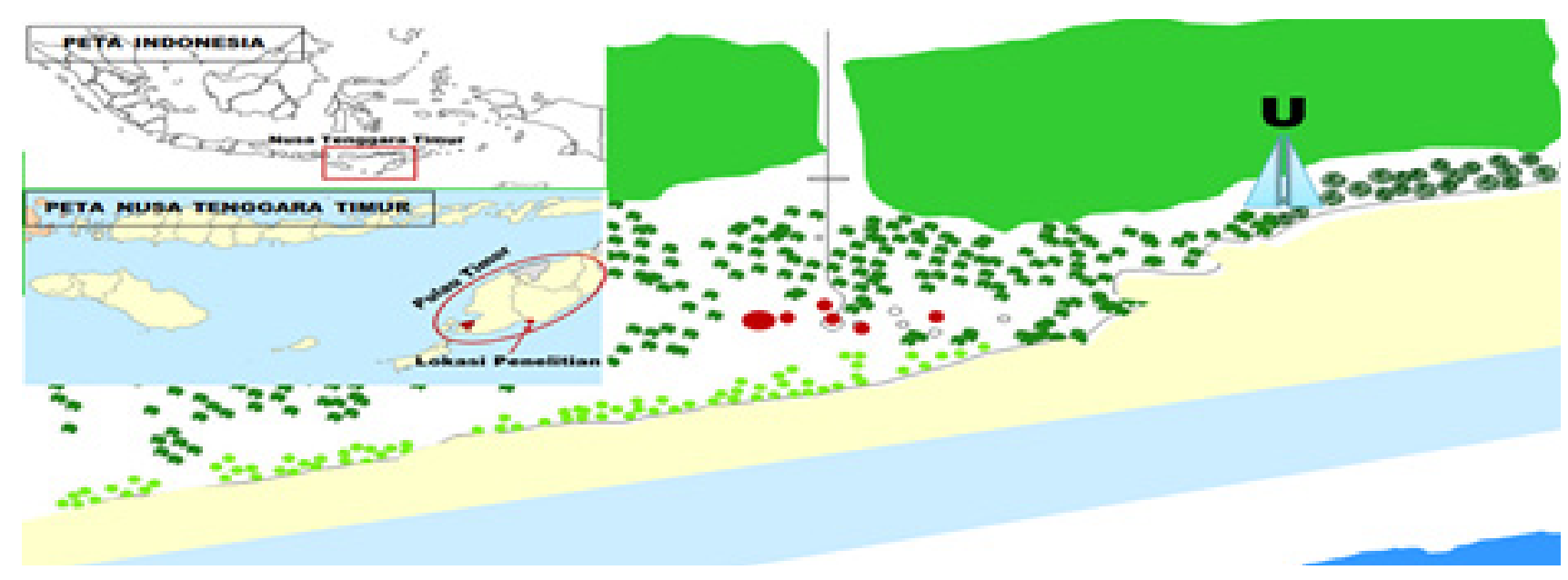

Gambar 1.

Peta Lokasi Penelitian, Pantai Oetune

Sumber: Google Map, 2017

\section{Potensi Internal Pantai Oetune}

\section{Atraksi Tangible (Berwujud)}

Atraksi tangible (berwujud) dalam penelitian ini terbagi menjadi keunikan, variasi aktivitas, keindahan, keaslian/kealamian dan kebersihan.

\section{a. Keunikan}

Secara garis besar keunikan Pantai Oetune termasuk dalam kategori sangat potensial dengan bobot 4,37 . Dalam penilaian, firsttimer dan repeaters responden cenderung menilai bahwa Pantai Oetune sangat unik. Sedangkan responden dari luar NTT cenderung menilai unik.

Hal ini disebabkan karena responden luar NTT membandingkan dengan objek wisata sejenis yang pernah dikunjungi dan dirasa memiliki keunikan yang sama. Sedangkan wisatawan lokal, menilai sangat unik sebab Pantai Oetune merupakan. satu-satunya. pantai. di Pulau Timor yang memiliki keunikan berupa: 1) Gumuk pasir; 2) Sabana dalam kawasan; 3) Gradasi warna laut dan gulungan ombak 4) Bentang luas dan pola unik di paasir. luas dan pola unik dipasir; dan 5) Pemandangan dengan sekitar.

Berikut tabel penilaian responden.
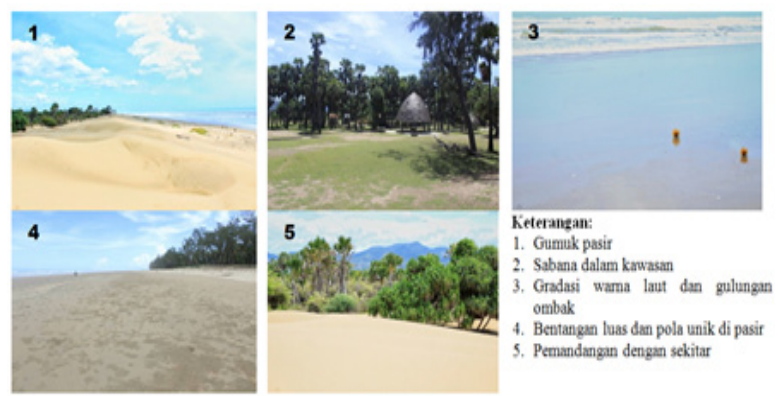

Gambar 2.

Keunikan Pantai Oetune

(Survei, 2017)

Keunikan Pantai Oetune juga dibandingan objek wisata yang memiliki keunikan sejenis (Pantai Parangtritis, Yogyakarta dan Gumuk Pasir Samalyuca, Meksiko). Hal ini dimaksudkan untuk memperkuat nilai potensial. Maka berikut hasil perbandingan tersebut.

1. Jenis pasir Pantai Oetune adalah pasir putih berbeda dengan gumuk pasir Pantai Parangtritis berwarna hitam. Warna pasir putih ini serupa dengan gumuk pasir Samaluyuca Meksiko. Perbedaannya adalah gumuk pasir Pantai Oetune merupakan gumuk pasir di pantai, sedangkan gumuk pasir Samalayuca merupakan gumuk pasir di gurun. 
2. Letak Pantai Oetune berbatasan dengan hutan dan gunung. Sehingga vegetasi yang terdapat

cukup variatif dan tumbuh dengan subur. Vegetasi ini berupa vegetasi laut yang terletak dalam kawasan, vegetasi hutan dan pengunungan. Hal ini dapat dikatakan unggul jika dibandingkan dengan Pantai Nihiwatu-Sumba yang meski masih alami, namun sistem biotik terletak agak jauh dan tidak terdapat sabana dalam kawasan.

3. Bentangan Pantai Oetune cukup luas dan landai, serta memiliki pola-pola unik di sepanjang pesisiran. Pola ini hanya terdapat di Pantai Oetune saja

4. Pantai Oetune memiliki keunggulan variasi pemandangan berupa: pemandangan pantai, laut, hutan, dan pemandangan yang berasal dari gunung

Berikut dokumentasi keunikan Pantai Oetune.

\section{b. Variasi Aktivitas}

Variasi aktivitas adalah aktivitas yang dilakukan pengunjung selama berada di pantai. Berdasarkan pengamatan, aktivitas tersebut berupa rekreasi, menikmati pemandangan, fotografi, berenang, berjalan-jalan sepanjang pesisiran pantai dan terkadang berolahraga (sepak bola). Penilaian responden berdasarkan perhitungan nilai potensial, maka hasil yang didapat berjumlah 3,75 atau termasuk dalam kategori potensial

Dalam penilaian ini meski terjadi kecenderungan menilai bahwa aktivitas cukup bervariatif. Akan tetapi, terjadi penurunan nilai oleh repeaters responden. Hasil wawancara terhadap salah satu repeaters responden mengatakan bahwa minimnya fasilitas pendukung aktivitas berwisata menyebabkan terjadinya penurunan nilai tersebut.

Menurut Fandeli (1996; Gadi Djou, 2013) menyebutkan bahwa secara umum variasi aktivitas wisata pantai dan bahari dapat diklasifikasikan menjadi 1) Wisata perairan atau wisata bahari; dan 2) Wisata daratan. Kegiatan bentang laut antara lain berenang, memancing, bersampan, menyelam yang meliputi diving dan snorkeling dan berselancar yang meliputi selencar air dan selancar angin serta berperahu parasut (parasailing). Sedangkan kegiatan bentang darat berupa olaraga susur pantai, bersepeda, panjat tebing pada dinding terjal pantai dan menelusuri gua pantai. Selain itu dapat melakukan aktivitas seperti bermain layang-layang, berkemah, berjemur, jalan-jalan melihat pemandangan, berkuda atau naik dokar pantai.

Maka berikut tabel 5 yang menunjukkan penilaian responden terhadap variasi aktivitas.

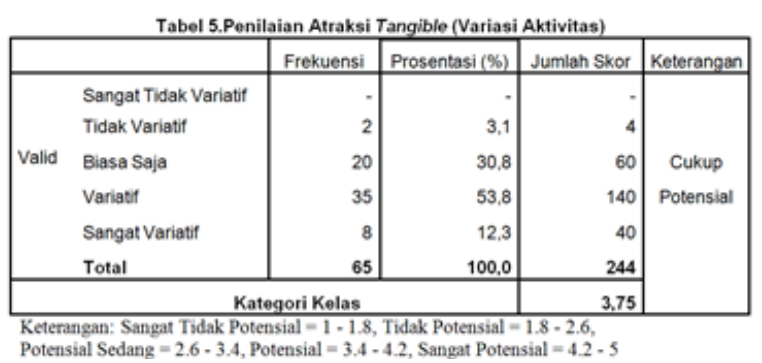

Jika dibandingkan dengan objek wisata sejenis lainnya. Misalnya Pantai Kuta terdapat pengelola yang menyediakan peralatan pendukung kegiatan berwisata di pantai. Seperti menyediakan peralatan selancar bagi wisatawan yang ingin berselancar dan kursi panjang untuk berjemur bagi wisatawan yang ingin menikmati sinar matahari. Penyediaan peralatan yang menunjang kegiatan berwisata juga dilakukan di Pantai Nihiwatu. Dari hal tersebut dapat disimpulkan bahwa variasi aktivitas terjadi apabila terdapat fasilitas yang mendukung aktivitas tersebut. Jadi, meski di Pantai Oetune variasi aktivitas dianggap cukup berpotensial, akan tetapi dalam pengembangannya perlu didukung oleh fasilitas penunjang.

\section{Keindahan}

Keindahan Pantai Oetune tidak hanya terbatas pada kawasan bentang darat dan bentang laut saja, tapi juga didukung oleh keberanekaragaman dan keselarasan. Secara keseluruhan, terjadi kecenderungan menilai sangat indah. Sebab Pantai Oetune memenuhikriteria keindahan pantai yaitu keindahan sebuah pantai dikatakan sangat 
potensial jika tidak hanya memiliki keindahan bentangan laut dan darat saja. Akan tetapi juga memiliki variasi pandangan pulau/gunung di laut, keindahan relief, kerindangan tepi pantai, keserasian pandangan pantai dengan sekitarnya serta memiliki ciri khusus.

Berikut tabel penilaian responden terhadap keindahan.

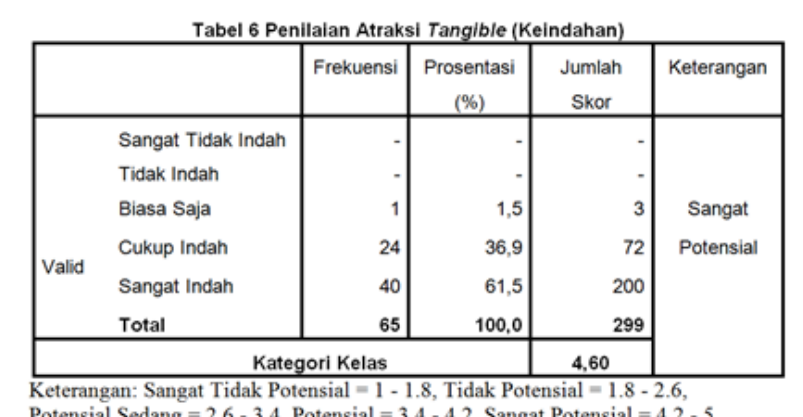

Potensial Sedang $=2.6-3.4$, Potensial $=3.4-4.2$, Sangat Potensial $=4.2-5$

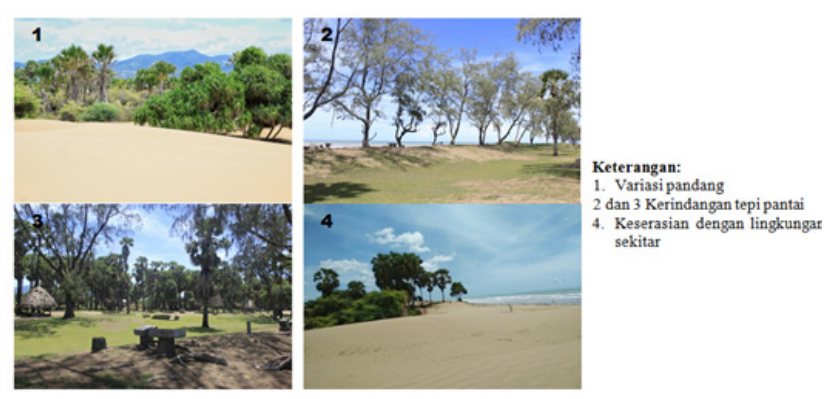

Gambar 3.

Keindahan Pantai Oetune

(Survei, 2017)

Pada gambar 3 tersebut di atas menunjukan keindahan Pantai Oetune berdasarkan kriteria keindahan pantai.

Beikut penjelasan keunggulan keindahan Pantai Oetune apabila dibandingkan dengan objek wisata sejenis.

1. Variasi Pandang

Pantai Oetune memiliki variasi pandang yang variatif oleh karena pantai berbatasan langsung dengan hutan dan pegunungan. Sehingga variasi pandang berupa pemandangan laut, hutan dan pegunungan.

2. Kerindangan Tepi Pantai

Oleh sebab Pantai Oetune berbatasan langsung dengan hutan dan pegunungan, maka tepi pantai cukup rindang. Sebab lingkunganbiotik pendukung kerindangan berasal dari biotik laut, biotik hutan dan biotik pegunungan. Komponen kerindangan ini tumbuh dengan subur sesuai dengan iklim tropis.

3. Keserasian dengan Lingkungan Sekitar

Pada umumya kerserasian pantai lingkungannya terjadi akibat adanya interaksi dari elemen warna laut, warna biru langit dan warna pasir. Di Pantai Oetune keserasian dengan lingkungan dianggap memiliki keunggulan oleh sebab terbentuk oleh intaraksi elemen dari warna biru laut, warna biru langit, warna pasir putih serta warna hijau yang berasal dari pemandangan hutan dan pegunungan.

\section{d. Kealamian/Keaslian}

Keaslian/kealamian pantai yang dimaksud adalah wisata yang belum didesain ulang oleh manusia. Pantai Oetune merupakan pantai yang masih sangat alami, beberapa fasilitas yang dibangun di sekitar kawasan pun terbuat dari material dari alam, sehingga sampai saat penelitian ini dilakukan, kawasan pantai masih sangat mendukung pelestarian lingkungannya.

Penilaian oleh responden dan pengamatan langsung menghasilkan bobot nilai 4,86 atau termasuk dalam kategori sangat potensial. Responden cenderung menilai sangat indah. Hal ini disebabkan oleh karena pantai masih sangat mendukung kelestariannya seperti pada penjabaran sebelumnya.

Berikut penilaian responden terhadap kealamian/keaslian.

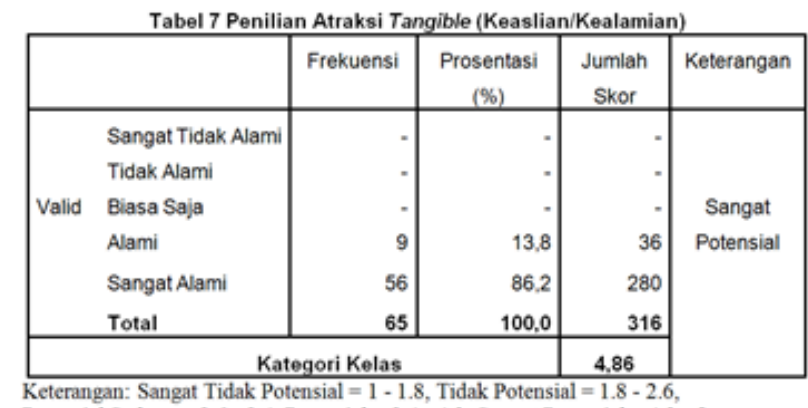

Potensial Sedang $=2.6=3.4$, Potensial $=3.4-4.2$, Sangat Potensial $=4.2-5$ 


\section{e. Kebersihan}

Kebersihan yang dimaksud adalah kebersihan air laut dan kebersihan dalam kawasan. Kriteria kebersihan air berupa tidak ada pengaruh pelabuhan, tidak ada pengaruh pemukiman, tidak ada pengaruh sungai, tidak ada pengaruh pelelangan/pabrik/pasar, tidak ada sumber pencemaran serta tidak ada pengaruh terhadap iklim. Sedangkan kebersihan dalam kawasan termasuk di dalamnya sampah, vandalisme, bebas kebisingan, tidak banyak gangguan binatang, bebas bau dan sedikit kerikil/kerang tajam (Soemarno, 2010).

Masalah persampahan di pantai ini terpengaruh oleh aliran sungai dan iklim. Pada saat musim hujan, sampah alam baisanya terbawa arus dan mengotori pesisiran. Tetapi tidak mempengaruhi kejernihan air laut

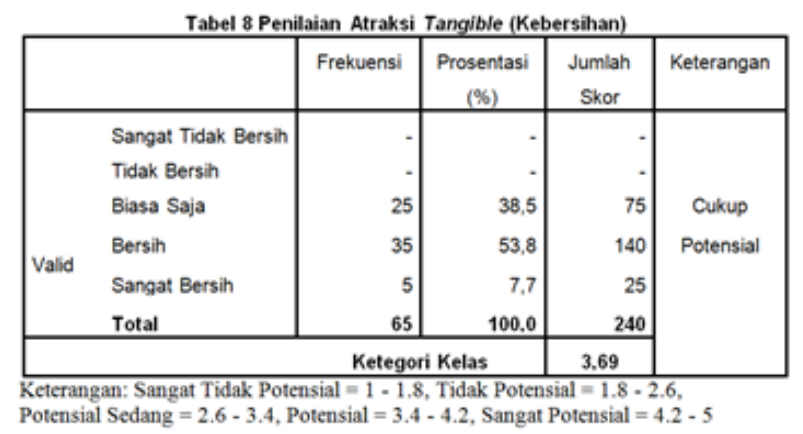

Tabel 8 tersebut di atas, merupakan penilaian responden terhadap kebersihan. Jika dilihat dari penilaian responden, memiliki kecenderungan menilai cukup bersih dan bobot 3,69 atau termasuk dalam kategori potensial.

Dalam pengembangannya, Pantai Oetune memerlukan fasilitas dan manajemen persampahan. Sebab, sampai penelitian ini dilakukan, kepengelolaan terhadap sampah belum teroganisir. Sampah-sampah dari aliran sungai atau sampah dari wisatawan biasanya akan dikumpulkan dan dibakar oleh anak-anak yang berjualan di sekitar pantai.

\section{Atraksi Intangible (Tidak Berwujud)}

Atraksi intangible atau tidak berwujud dalam penelitian ini mencakup hal berikut. a. Pengalaman

Pengalaman terhadap suatu perjalanan wisata pada dasarnya dapat meningkatkan loyalitas pengunjung terhadap pariwisata. Penilaian pengalaman oleh responden di Pantai Oetune memiliki kecenderungan cukup baik. Maka hasil nilai yang didapat berjumlah 4,22 atau termasuk dalam kategori sangat potensial.

Hasil penilaian terhadap pengalaman berkaitan dengan motivasi perjalanan serta kegiatan yang dilakukan saat berwisata. Meski oleh responden menganggap pengalaman yang dirasakan selama berada di Pantai Oetune memiliki kecenderungan cukup baik, namun untuk meningkatkan kualitas nilai potensial dari pengalaman, maka kualitas pelayanan objek wisata dan fasilitas pendukung kegiatan berwisata perlu ditingkatkan.

b. Kepuasan

Kepuasan yang dimaksud adalah suatu keadaan dimana keinginan, harapan dan kebutuhan dari wisatawan terpenuhi. Suatu pelayanan objek wisata dinilai sangat memuaskan jika pelayanan tersebut dapat memenuhi kebutuhan dan harapan wisatawan. Hasil penilaian menunjukkan bahwa terjadi kecenderungan menilai cukup puas dan sangat potensial. Sehingga bobot nilai yang dihasilkan berjumlah 4,42.

Kepuasan di Pantai Oetune disebabkan oleh kualitas daya tarik. Namun, kepuasan tersebut kurang didukung oleh amenitas dan kepengelolaan. Oleh karena itu, dalam pengembangannya kepuasaan wisatawan perlu ditingkatkan dengan cara menyediakan fasilitas dan kepengelolaan sesuai kebutuhan wisatawan.

c. Kesenangan

Salah satu tujuan dari pariwisata agar wisatawan mendapatkan kesenangan. Jika wisatawan merasa senang selama melakukan kunjungan kembali, maka akan ada kemungkinan untuk berkunjung kembali. 
Kesenangan di Pantai Oetune termasuk dalam kategori sangat potensial dengan jumlah bobot nilai 4,46. Kesenangan ini dianggap cukup oleh responden. Namun terjadi penurunan nilai first-timer terhadap repeaters dan responden dari luar NTT. Penurunan nilai ini terjadi oleh sebab menurut responden selain daya tarik, faktor komponen pedukung kesenangan lainnya yaitu amenitas masih minim. Maka dalam pengembangannya ketersediaan komponen amenitas perlu dipertimbangkan.

d. Kenangan

Kenangan merupakan kesan yang melekat pada pengunjung pada ingatan dan perasaan pengunjung saat berada di Pantai Oetune. Penilaian terhadap kenangan berbotot 4,28 atau sangat portensial dengan kecenderungan responden menilai cukup baik.

Pengaruh kenangan terbesar pengunjung disebabkan oleh daya tarik yang dimiliki dan pengalaman saat berada di pantai. Dalam meningkatkan kenangan, perlu dipertimbangkan ketersediaan cinderamata. Sebab Pantai Oetune belum memiliki cinderamata. Jadi, meski kenangan oleh responden memiliki nilai sangat baik (berdasarkan daya tarik), akan tetapi secara keseluruhan kenangan di Pantai Otune masih dianggap cukup.

e. Keamanan

Keamanan adalah suatu kondisi dimana wisatawan dapat merasa aman baik bagi keselamatan jiwa dan fisik selama berada di lokasi. Hasil penilaian menunjukkan bahwa keamanan Pantai Oetune termasuk dalam kategori sangat potensial atau dengan bobot 4,43. Penilaian ini memiliki kecenderungan cukup aman. Hal ini disebabkan oleh karena Pantai Oetune tidak ada arus balik, tidak ada kecuraman, bebas gangguan binatang bahaya dan tidak ada kepercayaan yang mengganggu. Namun oleh beberapa responden menyarankan adanya penjaga pantai dan menara pengawas yang memperhatikan keselamatan pengunjung.

\section{Potensi Eksternal}

\section{Aksesibilitas}

Aksesibilitas dalam penelitian ini mencakup hal sebagai berikut.

a. Pencapaian

Pantai Oetune termasuk dalam kategori sangat potensial. Hal ini dikarenakan lokasi pantai terletak di antara 2 pintu masuk udara yaitu Bandara El-Tari-Kupang dan Bandara Internasional Presidante Nicolau Labato-Timor Leste. Sedangkan berdasarkan penilaian responden, maka terjadi kecenderungan menilai cukup baik. Maka pencapaian termasuk dalam kategori potensial dengan bobot 4,00.

b. Kondisi Jalan

Kondisi jalan saat ini dianggap cukup baik sebab jalan menuju kawasan merupakan jalan strategis negara. Akan tetapi, sekitar + 300 m sebelum masuk kawasan, jalan masih berupa pengerasan dan sempit. Jalan ini licin dan becek pada saat musim hujan. Maka responden cenderung menilai kondisi jalan cukup baik dengan bobot 3,94 dan termasuk dalam kategori potensial.

c. Jarak Tempuh

Data yang diperoleh menunjukkan bahwa sebagian besar responden menempuh lebih dari $50 \mathrm{~km}$ untuk mencapai lokasi. Tetapi, responden cenderung menilai tidak terganggu. Sehingga termasuk kategori potensial atau dengan bobot 3,83.

d. Waktu Tempuh

Waktu tempuh rata-rata responden untuk sampai ke lokasi 2-5 jam. Sama halnya dengan jarak tempuh, responden tidak merasa terganggu dengan waktu tempuh. Bobot penilaian waktu tempuh dianggap potensial dengan jumlah bobot 3,85.

e. Jenis Kendaraan yang digunakan

Berdasarkan hasil pengamatan, meski jenis kendaraan dan frekuensi kendaraan umum menuju lokasi dianggap cukup baik, namun responden lebih memilih menggunakan kendaraan pribadi. Hal ini disebabkan. responden merasakurang nyaman dengan 
kendaaran yang tersedia maka hasil bobot berjumlah 3,38 atau potensial sedang.

f. Jarak dengan Objek Daya Tarik Sejenis Hasil pengamatan menunjukkan bahwa terdapat ODTW sejenis dengan jarak $+15 \mathrm{~km}$ dari Pantai Oetune yaitu Pantai Kolbano. Akan tetapi, atraksi yang ditawarkan berbeda satu sama lain. Jika Pantai Oetune memiliki pasir dengan bentangan luas dan landai, maka Pantai Kolbano menawarkan keindahan bebatuan. Selain itu, Pantai Oetune memiliki kerindangan tepi pantai. Sehingga Pantai Oetune termasuk dalam kategori potensial dengan nilai 4 . Berikut dokumentasi perbedaan Pantai Oetune dengan Pantai Kolbano.

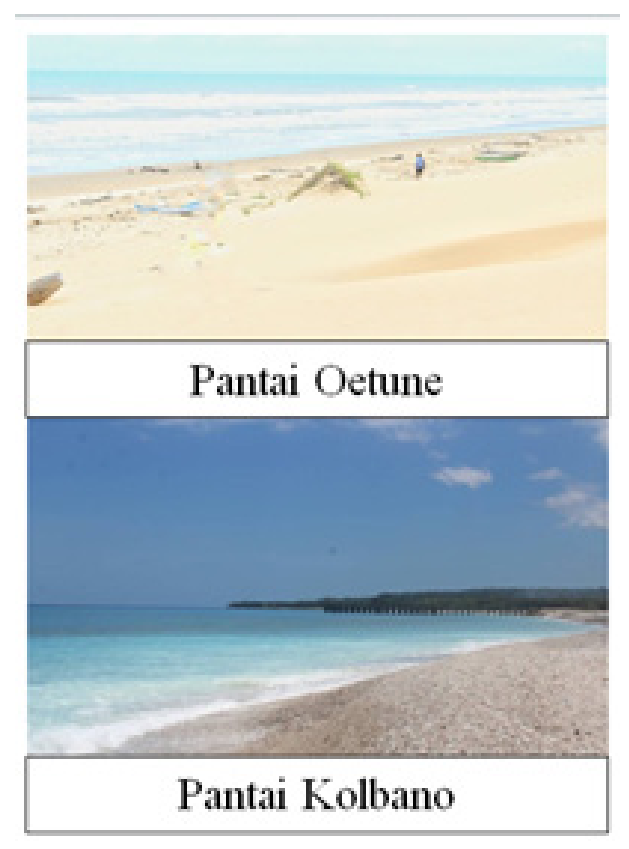

\section{Amenitas}

Amenitas yang dimiliki Pantai Oetune saat ini berupa satu buah fasilitas penginapan, fasilitas pujasera yang aktif pada saat weekend dan libur nasional, satu buah papan penunjuk arah, empat buah bak sampah, dua MCK dan beberapa fasilitas isitirahat. Kategori nilai berdasarkan pengamatan adalah kurang potensial dengan bobot 2,14.

Maka dalam pengembangannya, amenitas perlu ditingkatkan sesuai dengan kebutuhan wisatawan. Berikut ini penilaian kebutuhan amenitas oleh responden.

1) Fasilitas penginapan termasuk dalam kategori membutuhkan dengan bobot 3,98.

2) Fasilitas rumah makan termasuk dalam kategori sangat membutuhkan dengan bobot 4,72 .

3) Fasilitas informasi termasuk dalam kategori sangat membutuhkan dengan bobot 4,25.

4) Fasilitas penunjang berupa $\mathrm{MCK}$, kebersihan dan penerangan berada pada kategori sangat membutuhkan dengan bobot 4,86.

5) Fasilitas parkir termasuk dalam kategori membutuhkan dengan bobot 3,95.

6) Kios cinderamata termasuk dalam kategori membutuhkan dengan bobot 3,92.

7) Ketesediaan air bersih termasuk dalam kategori sangat membutuhkan dengan bobot 4,92.

Berdasarkan hasil pembobotan nilai tersebut dapat disimpulkan bahwa kebutuhan terbesar pengunjung Pantai Oetune adalah tersedianya air bersih.

\section{Kepengelolaan (lembaga) dan Sumber Daya Manusia}

Berdasarkan hasil penelitian, kondisi kepengelolaan masih sangat sangat minim. Maka penilaian termasuk katagori sangat butuh. Nilai kebutuhan tersebut yaitu 1) Manajemen dengan bobot 4,65 atau sangat membutuhkan; 2) Pengelolaan fasilitas pendukung dengan bobot 4,66 atau sangat membutuhkan; 3) Kelengkapan fasilitas dengan bobot 4,86 atau sangat membutuhkan; 4) Mutu pelayanan dengan bobot 4,48 atau sangat membutuhkan: 5) peningkatan SDM dengan bobot 4,62 atau sangat membutuhkan; dan 5) Promosi dan pemasaran dengan bobot 4,48 atau sangat membutuhkan.

\section{Potensi dan Pengembangan Pasar Wisatawan}

Hasil pembobotan nilai menunjukkan pasar wisatawan yang paling potensial adalah 1) Wisatawan lokal berbobot 4,55 dan termasuk kategori sangat potensial; 2) Pasar wisatawan nusantara berbobot 4,32 dan termasuk kategori 
sangat potensial; serta 3) Pasar wisatawan luar negeri berbobot 4,23 dan termasuk kategori sangat potensial.

Berdasarakan wawancara, oleh responden penilaian pasar wisatawan nusantara dan luar negeri akan meningkat jika kualitas fasilitas dan pengelolaan telah ditingkatan.

\section{Strategi Pengembangan Potensi Internal dan Eksternal}

Berdasarkan hasil pembobotan nilai responden pengamatan dan studi literatur, maka berikut ini rekomendasi strategi pengembangan dalam meningkatkan potensi objek wisata alam Pantai Oetune.

\section{Strategi Pengembangan Potensi Internal}

a. Atraksi Tangible (Berwujud)

Pantai Oetune adalah objek wisata alam yang timbul oleh karena minat khusus terhadap keindahan, keunikan dan kealamian/ keasliannya. Maka arahan pengembangan sebaiknya berdasar pada pariwisata berkelanjutan untuk menjaga kelestarian dan kebersihan lingkungan pantai.

b. Atraksi Intangible (Tidak Berwujud)

Atraksi intangible merupakan atraksi yang dirasakan oleh pengunjung selama melakukan aktivitas wisata. Maka atraksi ini memiliki keterkaitan erat dengan fasilitas pendukung dan kepengelolaan. Rekomendasi pengembangan yang sesuai adalah kelengkapan fasilitas pendukung aktivitas dan meningkatkan manajemen kepengelolaan di dalam kawasan.

\section{Strategi Pengembangan Potensi Eksternal}

a. Aksesibilitas

Secara garis besar aksesibilitas dianggap cukup potensial. Hal ini dikarenakan posisi Pantai Oetune yang terletak diantara 2 pintu masuk jalur udara. Selain itu, akses menuju lokasi juga didukung oleh status jalan raya yang merupakan jalan negara dan jalan strategis nasional. Pertimbangan untuk aksesibilitas adalah jalan masuk kawasan yaitu sepanjang +300 meter yang masih berupa jalan pengerasan. Selain itu perlu juga memperhatikan ketersediaan dan kenyamanan transpotasi lokal

b. Amenitas

Rekomendasi strategi pengembangan amenitas Pantai Oetune disesuaikan dengan kebutuhan wisatawan. Berdasarkan penilaian, kebutuhan yang menjadi prioritas wisatawan adalah ketersediaan air bersih, fasilitas kebersihan, MCK dan penerangan.

c. Kepengelolaan (Lembaga) dan SDM

Prioritas pengembangan untuk kepengelolaan (lembaga) dan SDM dilakukan dengan cara meningkatkan kerjasama antar pihak-pihak kepariwisataan.

\section{KESIMPULAN DAN SARAN}

\section{Kesimpulan}

Kesimpulan ini merujuk pada jawaban atas pertanyaan penelitian yaitu:

1. Kondisi potensi kepariwisataan di destinasi wisata alam Pantai Oetune termasuk dalam kategori sangat potensial. Atraksi berwujud yang menjadi daya tarik utama adalah keaslian/kealamian, keindahan (variasi pemandangan, kerindangan tepi pantai dan keserasian dengan lingkungan sekitar) dan keunikan (gumuk pasir, sabana dalam kawasan gradasi warna air laut, bentangan dan pola unik serta pemandangan dengan sekitar). Keindahan dianggap sangat potensial sebab menawarkan variasi pandangan, kerindangan tepi pantai dan keserasian dengan lingkungan yang dianggap berbeda dengan pantai sejenis lainnya di Pulau Timor. Keunikan dianggap sangat potensial sebab Pantai Oetune merupakan satu-satunya pantai di Pulau Timor yang memiliki gumuk pasir, sabana dalam kawasan, bentangan luas dengan pola unik menyebar sepanjang pesisir serta memiliki variasi pemandangan berupa gunung dan hutan. Pencapaian juga dianggap sangat potensial, sebab pantai relatif mudah dicapai oleh wisatawan 
Bandar udara El-Tari Kupang menjadi akses melalui udara, demikian pula bandar udara Internasional Presidante Nicolau Labato, Timor Leste.

2. Pengembangan potensi yang sesuai dengan ekspektasi wisatawan adalah Pantai Oetune tetap menjaga kelestarian lingkungan dan meningkatkan amenitas serta peningkatan kualitas keprofesional lembaga dan SDM.

3. Faktor paling berpengaruh terhadap peningkatan potensi adalah faktor lingkungan yang terjaga kelestariannya. Sebab lingkungan merupakan faktor utama yang menyajikan keunggulan atraksi.

\section{Rekomendasi}

Rekomendasi pengembangan potensi kepariwisataan destinasi wisata alam Pantai Oetune yaitu 1) Mempertahankan daya dukung dan kualitas lingkungan dengan membuat regulasi; 2) Memilihara kondisi lingkungan dengan mencegah pemanfaat daerah yang peka terhadap kerusakan dengan cara zonasi untuk aktivitas wisata jangka panjang; 3) Menyediakan amenitas yang disesuaikan dengan.... kebutuhan wisatawan; 4) Meningkatkan SDM dan kepengelolaan; 5) Meningkatkan kerjasama dengan sektor wisata terkait; dan 6) Promosi dan pemasaran dilakukan pada segmentasi pasar yang disesuaikan dengan potensi yang dimiliki Pantai Oetune.

\section{DAFTAR PUSTAKA}

Akdon dan Riduwan. (2001). Rumus dan Data Untuk Penelitian (administrasi pendidikan-Bisnis-Pemerintahan-SosialKebijakan-Ekonomi-HukumManajemen). Bandung: Alfabeta

Gadi Djou, JA. (2013). Pengembangan 24 Destinasi Wisata Bahari Kabupaten Ende. Jurnal: Kawistara No 1, 21 April 2013

Hermalita, Anggraeni. (2014). Elemen dan Faktor Pembentuk Ruang Terbuka Publik di Kawasan Pantai Melawai Balikpapan Berdasarkan Presepsi Pengguna Ruang. Universitas Gadjah Mada, Yogyakarta.

Lasally, Adesty. (2015). Kualitas Daya Tarik Wisata Alam dan Budaya Kawasan Tanjung Setia dan Kawasan Pulau Pisang di Kabupaten Pesisir Barat, Provinsi Lampung. Universitas Gadjah Mada, Yogyakarta.

NTT Akan Bangun Bandara Internasional.

( h t t p : / / w w w. s i n a r h a r a pan . c o / n e w s / r e a d / $31124 /$ nttakanbangunbandarainternasional, diunduh 06 April 2016)

NTT Benahi Infrastruktur wisata Utama.

( h t t p : / / b k p m n t t p r ov.web.id / nttbenahiinfrastrukturwisatautama/, diunduh 18 April 2016)

Pitana dan Diarta. 2009. Pengantar Ilmu Pariwisata. Yogyakarta: CV Andi Offset.

Soermarno. (2010). Metode Analisis Potensi wilayah Wisata Alam. Bahan Kajian. 